\title{
Research on the Course of Academic Thesis Writing based on the Teaching Reform
}

\author{
Ni Wang* \\ Inner Mongolia Honder College of Arts and Sciences, Hohhot 010070, Inner Mongolia, China \\ *Corresponding author: Ni Wang, hengshan.1990@163.com
}

\begin{abstract}
Recently, the State Council has set higher standards for the graduation thesis of undergraduates. Most undergraduate colleges and universities have issued their own policies in which private colleges and universities have paid more attention to this issue in which several local experts have conducted many research on the course of academic thesis writing. The Inner Mongolia Honder College of Arts and Sciences is used as an example in this article. Using the questionnaire survey and interview method, the current situation of the academic thesis writing course in private colleges is analyzed and its reform in private colleges and universities is explored in hope to provide some reference for future research.
\end{abstract}

Keywords: Questionnaire survey; Graduation thesis; Private colleges

Publication date: June 2021; Online publication: June 30, 2021

\section{Introduction}

In October 2020, the Central Committee of the Chinese Communist Party and the State Council issued the general plan of "Deepening Educational Evaluation Reform in the New Era" which required strict academic standards and also explored the pilot work of random inspections on undergraduate graduation papers. In 2021, the Ministry of Education formulated and issued the "Measures for Sampling Inspection of Undergraduate Thesis (Design) (Trial)" which made it clear that the undergraduate graduation thesis will be conducted once a year. The sampling results will be linked with the contents of undergraduate education teaching evaluation and professional construction. This regulation has attracted social attention and caused undergraduate colleges and universities to focus more in this area. Tang Youjun and Ma Xiaomei have defined the concept of primary academic thesis writing and constructed a scale for academic thesis writing. ${ }^{[1]}$ In addition to that, Wang Qin used questionnaires and logs to examine the papers of English majors in which she suggests that teachers of graduation thesis should teach according to their aptitude whereas guidance should be emphasized on the contents. ${ }^{[2]}$ Yang Jianhong on the other hand, analyzed the current situation of English graduation thesis in independent colleges and found that through the paper, the students' preliminary scientific research skills are cultivated. ${ }^{[3]}$ This article explored the problems and countermeasures of private colleges in the academic thesis writing course and used Inner Mongolia Honder College of Arts and Sciences as an example in the aim to provide some enlightenment to similar colleges.

\section{Current situation of the academic thesis writing course in private colleges and universities}

\subsection{Research design}

This study included 291 students from Inner Mongolia Honder College of Arts and Sciences as research subjects. Through questionnaire and interview, the existing problems of private colleges and universities are analyzed. The questionnaire was set as follows: 
(1) Do you think it is difficult to write academic papers?

(2) Is it difficult to choose a topic in your paper?

(3) What is the biggest problem you have?

(4) Do you have a clear understanding of the paper after you have finished writing it?

(5) What are your expectations for the paper?

\subsection{Status quo}

291 questionnaires were distributed in this study but only 270 were recovered. 257 questionnaires out of the recovered questionnaires were valid and 13 questionnaires were invalid due to incorrect information being filled out. The details are as follows:

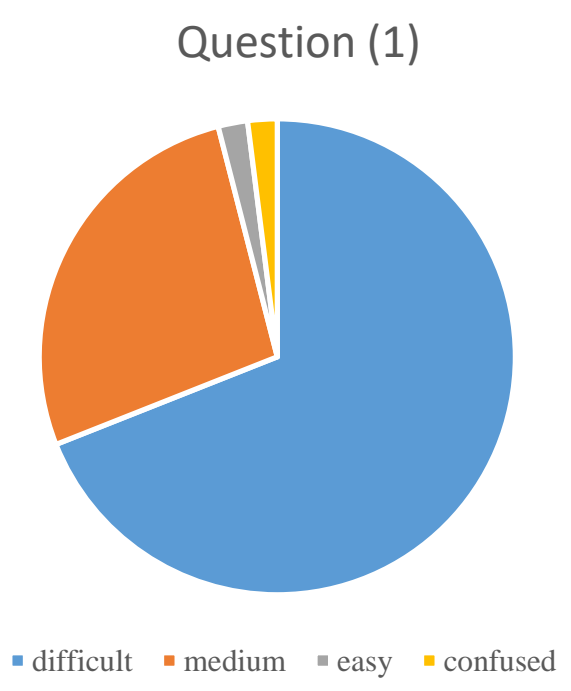

From the chart above, it is understood that most students thought that academic thesis writing is difficult, but there are some students that found it helpful and moderately difficult.

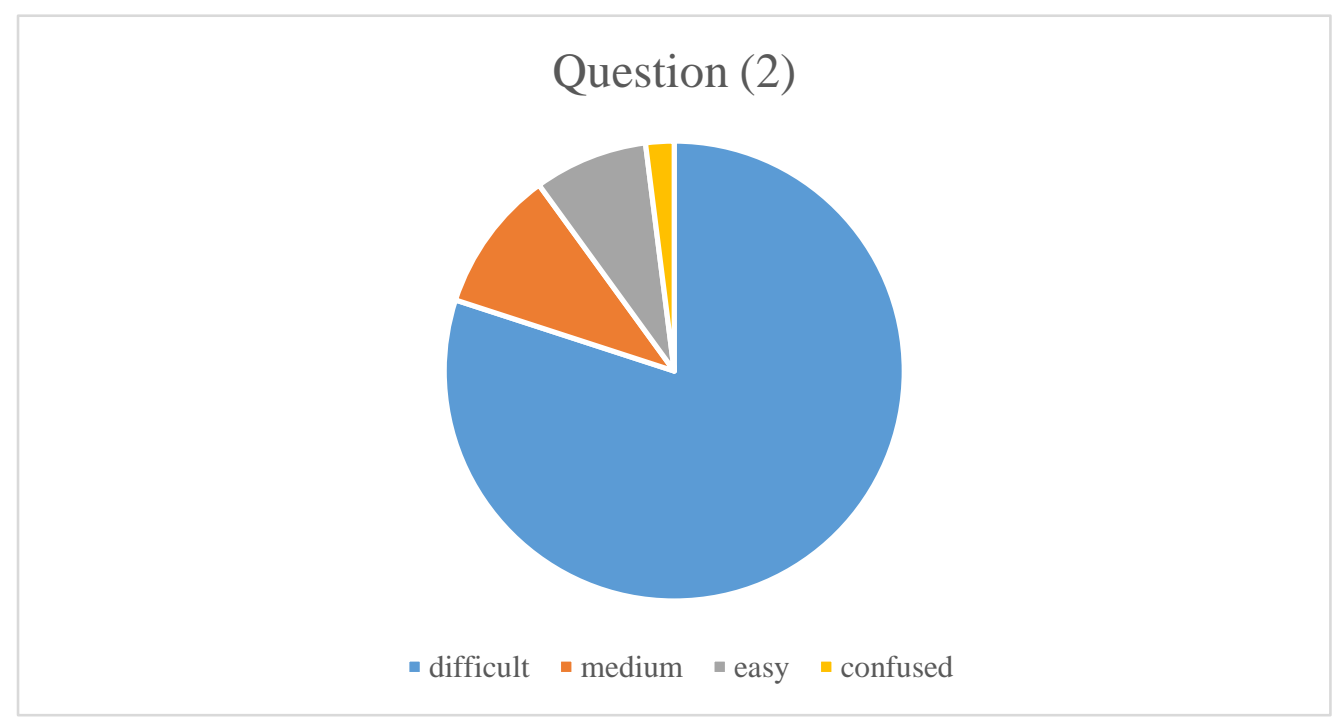

In question (2), $80 \%$ of the students thought that the course of choosing a topic was very difficult while only $18 \%$ thought it was moderate or easy. 
Based on the third question, students mainly gave the following answers:

a. The course is too theoretical to be used in the writing of graduation thesis

b. The direction of tutor research is different from that of self-research

c. There is little understanding of previous studies

d. Confused with the writing of the thesis

e. I have doubts about my ability and think I cannot finish my graduation thesis writing

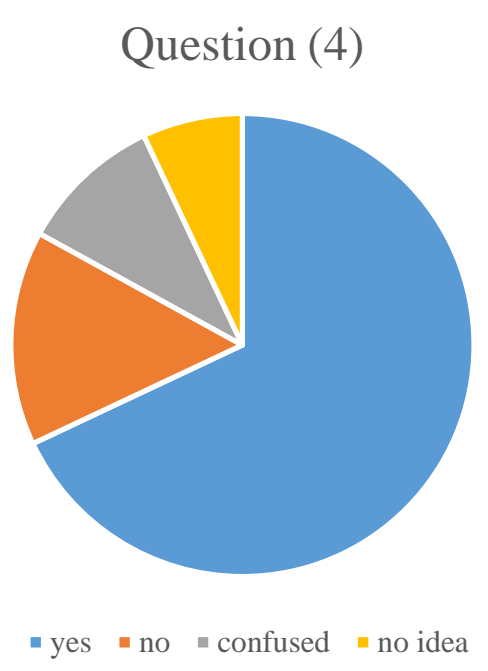

Based on the chart of question (4), most students had formed basic understanding of the paper after they had finished writing the paper, however some students have no clear understanding or are stills ambiguous about the content of the paper.

According to question (5), the students mainly provided the following answers:

a. Smooth graduation

b. To be selected as an excellent graduation thesis

c. Make a complete summary of undergraduate studies

\subsection{Reasons}

Through the questionnaire surveys and interviews, the main reasons of the above problems existing in the course of academic thesis writing are as follows:

A. Large number of students under a single tutor

With 7-10 students under only one tutor limits teaching according to their aptitude and restricts the guidance for each student. In this way, students are not able to fully understand the intention of their tutors, hence only having half the knowledge while writing their papers. The teachers' requirements for their students are also rigid and they neglect the differences of each individual students. In addition to that, there are very few numbers of full-time teachers in private colleges. While there are many external teachers, it is difficult to invite them which leads to a large number of papers brought on by these full-time teachers. This does not form a benign cycle and academic exchanges are not fully carried out.

B. Students lack scientific research skills

Students have not formed a complete knowledge system in their field of studies for several years. They have little knowledge about each part of the content, and they have not carried out in-depth research. Hence, they encounter difficulties in selecting their thesis topics. At present, most students would choose similar topics as previous students so their studies would have no new meaning to them. These articles published 
are not of great practical or theoretical value especially when many students in the same class select similar topics and lend their work to one another. In this way, the borrowed literature or content is not authoritative and the quality of the paper is poor which affects the evaluation of schools.

C. Poor theoretical and practical skills

Students only remember basic theories and methods during academic thesis writing. They are still unfamiliar with writing without practical trainings. The course lacks a lot of training in regard to theory and related literatures. If students are not allowed to write, the whole course would just be taught by teachers. Students have learned but they have also asked what they have learned which implies that they are in a confused state.

\section{Students do not know enough}

For many students, their goal is toward graduation, hence they do not take into consideration the value and importance of their graduation thesis. In addition to that, they do not pay attention to the course of academic thesis writing and their final thesis. The students brought by the authors do not even have any idea which parts are important when they are vivaed on their graduation thesis. Several students also do not denote the sources of their literature citations in addition to having misleading or missing notes are all over the text. These academic misconducts are not emphasized by students as they are just focused on completing their thesis.

\section{Suggestions and measures for the improvement of academic thesis writing in private colleges and universities}

Based on the above research, this article suggests reforms to the course of academic thesis writing in the following aspects.

\section{A. Regular training of teachers}

Teachers of the academic thesis writing course should be professionally trained by regularly attending local and international research classes with the latest research results. Teachers should not have a closed mind but actively participate in relevant training in order to teach better. In addition to that, since teachers play a decisive role in the writing of graduate papers, students should be taught to write papers accurately while establishing correct ideas. Scientific research skills are important for the development of schools. Hence, for private colleges and universities to sustainably develop, they need to carefully select their teachers in the academic thesis writing course. Teachers on the other hand, should select appropriate contents for academic thesis writing while students should learn academic thesis writing.

In the course of teaching, there is a need to summarize each part and conduct scientific research training based on these summaries. A student-centered teaching should be conducted in which teaching should be in accordance with their aptitudes and detailed guidance should be provided in regard to topic selections without affecting the normal progress of the class. For example, when choosing appropriate topics, students need to be taught to utilize the Chinese Knowledge Network database to accurately search for relevant information, eventually they would be able to find the most suitable one. If the only thing that is talked about is theoretical without considering reality, the cycle only repeats itself and it is even more difficult to conduct the graduation thesis work.

B. Improvement of the tutor distribution system

The number of students assigned to one tutor can be quite packed. It is necessary to guide students to complete their graduation thesis with quality and quantity. Students should not have the idea of making fun of it instead, tutors should form rigorous academic attitude among students, thus realizing the whole process of educating people and the teaching goals of the academic thesis writing course. At present, private colleges and universities are assigning students directly to teachers. Therefore, teachers who are in the direction of education may have students who write in the direction of translation and literature while 
teachers in the direction of translation may have students of the cultural aspects. This is not conducive in the guidance of teachers. Eventually, in order to facilitate communication, one side either the teachers or students would have to compromise, leading to unclear directions of the paper.

C. Adjustments of class hours

The academic thesis writing course is currently 36 hours which starts in the next semester of the third year. However, graduation thesis writing starts in September. The first 18 classes focus on theory while the latter 18 focus on practice. These lectures on academic writing should be conducted in the last semester of senior high school to lay a solid foundation for students.

\section{Case study}

Case 1: Student L

Situation: The graduation thesis of student L involves translation research of public signs. Using his or her hometown as an example, the thesis is of a unique idea. However, in the process of writing, the author is ambiguous about the paper and the selected examples are independent of his or her hometown. The literature review of the whole paper is 9 pages long but the translation part of the text is only 2 pages. The paper format is also chaotic.

Solution: First, the paper structure of student $\mathrm{L}$ is adjusted and his or her wrong views are corrected. Literature review is important, but the research of the academic paper is the most significant part. The content of the thesis is modified according to the structural adjustments and many examples are added again. Finally, the student passed smoothly and achieved good results with the thesis.

Process table of student L's paper

\begin{tabular}{|c|c|c|c|}
\hline First draft & 58 & Format error, content and topic are independent of each other, insufficient understanding of the paper \\
\hline Finalization & 86 & The format is correct, the content is closely related to the topic, and has its own views on the paper \\
\hline
\end{tabular}

\section{Case 2: Student B}

Situation: Student B is an active student in class but has poor academic performance, bad attitude, and insufficient understanding of the thesis. It is always considered that graduation thesis is like passing through a hostile field which leads to major content problems in student's graduation thesis. The title in the summary of student B is the topic of model text. The format of the full text reference document is wrong in addition to language errors. When the teacher raised the issues, student B still did not realize the mistakes.

Solution: The tutor of student B has trained him or her in scientific research skills considering the issues of the thesis so that student $\mathrm{B}$ has a new understanding of the graduation thesis. The tutor also taught student B to find relevant documents and make reasonable references from the Chinese Knowledge Network. In terms of careless issues, the tutor also gave serious guidance and revised the language errors one by one. The student then received high marks in the paper's defense.

Process table of student B's paper

\begin{tabular}{|c|c|l|}
\hline First draft & 56 & Wrong format, no reference, careless, full text syntax error \\
\hline Finalization & 79 & Correct format, no errors in language, reasonable structure \\
\hline
\end{tabular}




\section{Conclusion}

Private college students have their own unique characteristics. Hence, "How to correctly guide students in their graduation thesis?" and "How to combine them with the actual situation of the school?" are important issues. Through the questionnaire and analysis, by integrating existing resources, using more resource technology, improving teaching quality, improving teachers' scientific research level, arousing students' interest, integrating theory with practice, as well as allowing students to become the focus in classrooms, private colleges can continuously improve the course construction of academic thesis writing and improve the course content. There is a need to reflect and monitor their teaching to improve their own skills which would eventually also improve the research skills of private college students. The graduation thesis work of private colleges and universities is closely related to undergraduate evaluations and the construction of first-class disciplines. If the quality of these graduation thesis is not up to par, it will affect the development of the school and subsequently, affect the students' quality. Therefore, in the long run, the graduation thesis work of undergraduates must be of top priority in colleges and universities. Hopefully, this article would be able to help future generations and enlighten more experts and scholars to focus on the development of private colleges and universities.

\section{Disclosure statement}

The author declares no conflict of interest.

\section{References}

[1] Tang Y, Ma X, 2021, Construction and trial of the rating scale for English graduation thesis in application-oriented universities. Foreign language testing and teaching, (2).

[2] Wang Q, 2020, Analysis of the writing needs of English Majors' graduation thesis - based on the survey of eight universities in $\mathrm{ZJ}$ province. Language education, (8).

[3] Yang J, 2015, Construction of academic thesis writing course for English majors in independent colleges. Science and Education Guide, (1).

[4] Zhao X, 2019, Teaching reform of academic thesis writing for college English majors. Education and Teaching Research, (5).

[5] 2021, The Ministry of Education launched the pilot project of undergraduate thesis sampling. http://www.moe.gov.cn/jyb_xwfb/s5147/202101/t20210108_509143.html 